Relations industrielles

Industrial Relations

\title{
A Tribute to Jack Barbash, 1911-1994
}

\section{Jean Sexton}

Volume 49, numéro 3, 1994

URI : https://id.erudit.org/iderudit/050953ar

DOI : https://doi.org/10.7202/050953ar

Aller au sommaire du numéro

\section{Éditeur(s)}

Département des relations industrielles de l'Université Laval

\section{ISSN}

0034-379X (imprimé)

1703-8138 (numérique)

Découvrir la revue

\section{Citer ce document}

Sexton, J. (1994). A Tribute to Jack Barbash, 1911-1994. Relations industrielles / Industrial Relations, 49(3), 439-439. https://doi.org/10.7202/050953ar

Tous droits réservés @ Département des relations industrielles de l'Université Laval, 1994
Ce document est protégé par la loi sur le droit d'auteur. L’utilisation des services d'Érudit (y compris la reproduction) est assujettie à sa politique d'utilisation que vous pouvez consulter en ligne.

https://apropos.erudit.org/fr/usagers/politique-dutilisation/ 


\section{A TRIBUTE TO JACK BARBASH 1911-1994}

Our cohort of industrial relations researchers is fortunate to follow in the steps of a prior generation of role models who, through their work, dedication, and personal values demonstrated what this field of inquiry and action should be about. Jack Barbash was a leading figure in that prior generation.

But above all else, Jack was an inspiring teacher, and for me, a mentor who took to this role naturally, long before the term became fashionable. He introduced me to this field, and with his immutable personal style, sparked my interest, and more than any other person, shaped the values I bring to the study and practice of industrial relations.

Jack's passing comes at a time when we are all challenged to ask very basic questions about what we stand for in industrial relations, especially as those of us in the U.S. begin the long overdue task of modernizing our labor policies. This is fitting, because for Jack, values stood as the defining feature of the field of industrial relations. He put it best in his 1980 Presidential Address to the Industrial Relations Research Association:

"In a liberal society, the business of industrial relations is more than technique and know-how. It is also the values to which technique and know-how are directed. Equity, due process, fairness, rights, reasonableness, participation, incentive, alienation, privacy, democracy, self-determination, good faith, mutual survival, incrementalism, pragmatism, job satisfaction, order - these are some of the values our field has embedded into the practice of collective bargaining."

These are the principles Jack sought to instill in the generations of students lucky enough to wander through is classroom door, only to be entranced by the power of his ideas and depth of his knowledge and experience. Let's hope that we are up to the task of carrying these values forward into the next century. Nothing could serve as a more appropriate and lasting tribute to this remarkable teacher, scholar, and friend.

Massachusetts Institute of Technology

Thomas A. KochaN 